Arq. Bras. Med. Vet. Zootec., v.70, n.3, p.1004-1008, 2018

\title{
Communication
}

[Comunicação]

\section{Lipid profile of immunocastrated, castrated male and female pigs}

\author{
[Perfil lipídico de suínos machos castrados e imunocastrados e fêmeas] \\ F.R. Caldara ${ }^{1}$, L.S. Santos ${ }^{2}$, C.T. Santos ${ }^{3}$, L. Foppa ${ }^{4}$, R.G. Garcia ${ }^{1}$, I.A. Nääs ${ }^{1}$, \\ V.M.O.S. Nieto \\ ${ }^{1}$ Universidade Federal da Grande Dourados - Dourados, MS \\ ${ }^{2}$ Aluno de pós-graduação - Universidade Estadual Paulista "Júlio de Mesquita Filho" - Jaboticabal, SP \\ ${ }^{3}$ Aluno de pós-graduação - Universidade Estadual Paulista "Júlio de Mesquita Filho" - Botucatu, SP \\ ${ }^{4}$ Aluno de pós-graduação - Universidade Estadual de Londrina - Londrina, PR \\ ${ }^{5}$ Universidade Federal do Mato Grosso do Sul - Campo Grande, MS
}

Meat is a food that has high nutritional content, a source of highly biologically valuable protein, amino acids, complex-B vitamins, and minerals. However, some factors restrict its consumption by the population due to its association with cardiovascular problems and obesity. Despite its considerable share of the global meat market, there are myths related to the quality of pork. The amount of lipids and cholesterol in meat is the main responsible for this concept (Cosgrove et al., 2005). However, fatty acids present in pig carcasses are influenced by factors including sex and castration.

The male pig's castration in the global industry is a normal and important practice to avoid the carcass's "boar taint". An efficient alternative to enjoy the benefits of sex hormones on performance and carcass quality of males, besides eliminating unwanted odors, is immunocastration (Zamaratskaia et al., 2008). This technique has been widespread because it is less invasive or painful to the animal, resulting in meat with organoleptic qualities similar to those of animals subjected to surgical castration (Fonti-Furnols et al., 2008). Despite the importance of castration, little information is provided regarding the fatty acid composition in immunocastrated pigs.

Considering the above, this study aimed to evaluate the profile and fatty acid composition of intramuscular fat, cholesterol levels, and ether extract, in addition to the atherogenic index and

Recebido em 22 de maio de 2017

Aceito em 3 de novembro de 2017

E-mail: lufoppa@yahoo.com.br thrombogenic index in meat of immunocastrated male pigs in relation to females and castrated males.

This study was conducted according to the guidelines established by the Ethics Committee on Animal Use in Experimentation of the Universidade Federal da Grande Dourados (Brazil), under protocol no. 031/2013.

Forty-five genetically similar animals (Landrace $\mathrm{x}$ Large White) (15 females, 15 surgically castrated males, and 15 immunocastrated males) with initial weight of $25.2 \pm 2.8 \mathrm{~kg}$ and final weight of $90.3 \pm 2.7 \mathrm{~kg}$ were used. The animals were distributed in a completely randomized design in three treatments (T1 - females; T2 surgically castrated males; and T3 immunocastrated males) and three replicates with 15 pigs per treatment.

The castrated animals underwent orchiectomy on the seventh day of life. Immunocastrated animals were vaccinated against gonadotrophin-releasing factor, which is based on a synthetic analog of GnRH coupled to a large carrier protein. The animals received two subcutaneous doses of the vaccine. The first dose primes the immune system of pigs, without altering the size or function of testicles, and was applied 60 days before slaughter (80 days old). The second dose was given 30 days before slaughter (110 days old) and stimulated the protective immune response to inhibit testicle function and lower the plasma concentration of testosterone. 
At the end of the finishing phase, the animals were fasted for a solid diet for $8 \mathrm{~h}$ and then transported to the slaughterhouse. Before carcass cooling, samples of the longissimus dorsi muscle were taken at the $\mathrm{P} 2$ point (insertion region of the last thoracic vertebra with the first lumbar vertebra, $6 \mathrm{~cm}$ from the dorsal line). After removal of superficial fat, the samples were lyophilized before analysis.

The levels of fat were determined by Soxhlet extraction for $20 \mathrm{~h}$ according to the methods approved by the AOAC (Official..., 2011).

The determination of cholesterol levels of longissimus dorsi muscle samples was performed by the enzymatic method using laboratory kits by Laborlab S/A, composed of two color reagents (number 1 containing $0.025 \mathrm{~mol} / \mathrm{L} \quad 4$ aminophenazone and number 2 containing $0.055 \mathrm{~mol} / \mathrm{L}$ of phenol) and the reactive enzyme (cholesterol oxidase 3U/mol POD 20U/mol, Lipase $300 \mathrm{U} / \mathrm{mol}$ ). The reagent was prepared by adding $0.5 \mathrm{~mL}$ of color reagent number $1,0.5 \mathrm{~mL}$ of color reagent number $2,19 \mathrm{~mL}$ of distilled water, and $0.4 \mathrm{~mL}$ of the enzyme reagent. The samples were added with $3 \mathrm{~mL}$ of the reagent and heat treatment was conducted for $10 \mathrm{~min}$ at $37^{\circ} \mathrm{C}$ in a water bath. After samples stood for $90 \mathrm{~min}$, absorbance was read against the blank, also prepared at $499 \mathrm{~nm}$. The calibration curve was constructed from a standard solution of cholesterol $\quad(1.006 \mathrm{mg} / 100 \mathrm{~mL}), \quad$ with concentrations ranging from 0.01 to $0.05 \mathrm{mg} / \mathrm{mL}$.

The fatty acid profile was determined by lipid extraction with chloroform and methanol, followed by the method in which the fat is saponified with potassium hydroxide and by esterification with sulfuric acid in methanol.

The analysis of methyl esters of fatty acids was done using a gas chromatograph (Shimadzu, model gc-17a) equipped with a flame ionization detector, a split/splitless injector, and a fused silica capillary column containing polyethylene glycol as stationary phase (db-wax, 60m x $0.25 \mathrm{~mm}, \mathrm{~J} \& \mathrm{~W}$ Scientific). Injector temperature was set to $230^{\circ} \mathrm{C}$. The initial column temperature was $80^{\circ} \mathrm{C}$ for $2 \mathrm{~min}$ at a rate of $3^{\circ} \mathrm{C}$ per minute, was raised to $180^{\circ} \mathrm{C}$ at $30^{\circ} \mathrm{C}$ per minute and was kept at this temperature for $30 \mathrm{~min}$. After this time, the temperature was increased to $200^{\circ} \mathrm{C}$ at a rate of $3^{\circ} \mathrm{C}$ per minute and remained at this temperature for $108 \mathrm{~min}$.

Fatty acids were identified by comparing their retention times with that of the methyl ester standards (Sigma-Aldrich) and the measurement was carried out by area normalization with results expressed as percentage of the area of each fatty acid over the total area of fatty acids (\%).

The identified and quantified fatty acids were the following: lauric (C12:0), myristic (C14:0), palmitic (C16:0), palmitoleic $(\mathrm{C} 16: 1)$, stearic (C18:0), oleic $(\mathrm{C} 18: 1 \mathrm{n} 9 \mathrm{c})$, linoleic $(\mathrm{C} 18: 2 \mathrm{n} 6)$, gamma-linolenic (C18:3n6), alpha-linolenic (C18:3n3), eicosenoic (C20:1n9), eicosadienoic (C20:2n6), arachidonic (C20:4n6), and eicosapentaenoic (C20:5n3). The total concentrations of saturated fatty acids (SFA), unsaturated fatty acids (UFA), monounsaturated fatty acids (MUFA), polyunsaturated fatty acids (PUFA), and omega 6: omega 3 ( $\omega 6: \omega 3)$ ratio were evaluated.

The atherogenic (AI) and thrombogenic (TI) index were evaluated as suggested by Ulbricht and Southgate (1991) (equations 1 and 2).

$\mathrm{AI}=(\mathrm{L}+4 \mathrm{M}+\mathrm{P}) /(\Sigma(\omega-6)+\Sigma(\omega-3)+\mathrm{O}+$ M')

$\mathrm{TI}=(\mathrm{M}+\mathrm{P}+\mathrm{S}) /\left(0.5 \mathrm{O}+.05 \mathrm{M}^{\prime}+0.5 \Sigma(\omega-6)+\right.$ 3) $+\Sigma(\omega-3 / \Sigma(\omega-6))$

Where: $\mathrm{L}=$ lauric acid $(\mathrm{C} 12: 0)$

$\mathrm{M}=$ myristic acid (C14:0)

$\mathrm{P}=$ palmitic acid (C16:0)

$\omega-3$ and $\omega-6=$ polyunsaturated fatty acids of omega 3 and 6 families

$\mathrm{O}=$ oleic acid (C18:1)

$\mathrm{M}^{\prime}=$ remaning monounsaturated fatty acids

$\mathrm{S}=$ estearic acid (C18:0)

ANOVA was applied to mean values in the SAS 9.2 computer package (SAS, 2001) using the general linear model (GLM). Means composed by five animals for each treatment were compared using Tukey's test considering 5\% level of significance when F-test was significant for the variables.

No difference $(\mathrm{P}>0.05)$ was found in fat or cholesterol levels in intramuscular fat of immunocastrated males, surgically castrated males, or females (Table 1). The fatty acid 
profile, total content of saturated fatty acids (SFA), monounsaturated fatty acids (MUFA), and polyunsaturated fatty acids (PUFA) of intramuscular fat in the longissimus dorsi muscle and the atherogenic and thrombogenic indexes were not affected $(\mathrm{P}>0.05)$ by the sex of pigs (Table 2).

Table 1. Ether extract (\%) and cholesterol $(\mathrm{mg} / 100 \mathrm{~g})$ of meat from immunocastrated males, barrows, and females

\begin{tabular}{ccccc}
\hline \multicolumn{5}{c}{ Treatment } \\
\hline & Immunocastrated & Female & Barrow & CV $(\%)$ \\
\hline Ether extract $(\%)$ & 6.63 & 4.98 & 5.98 & 20.30 \\
Cholesterol $(\mathrm{mg} / 100 \mathrm{~g})$ & 73.13 & 76.46 & 72.73 & 18.99 \\
\hline
\end{tabular}

*Values expressed in natural matter. CV - coefficient of variation.

Table 2 Fatty acid profile (\%) of the longissimus dorsi muscle of barrows, immunocastrated, males, and females

\begin{tabular}{lcccc}
\hline \multirow{2}{*}{ Fatty Acids } & \multicolumn{3}{c}{ Treatment } & P \\
\cline { 2 - 4 } & Barrow & Female & Immunocastrated & Value \\
\hline C12:0 & 0.013 & 0.041 & 0.003 & 0.520 \\
C14:0 & 1.137 & 1.137 & 0.999 & 0.216 \\
C16:0 & 31.859 & 27.068 & 28.396 & 0.725 \\
C18:0 & 13.964 & 16.827 & 17.082 & 0.621 \\
C16:1 n-7 & 3.168 & 3.380 & 3.277 & 0.323 \\
C18:1 n-9 & 33.490 & 34.0980 & 35.434 & 0.516 \\
C18:2 n-6 & 7.615 & 7.745 & 6.704 & 0.446 \\
C18:3 n-3 & 0.252 & 0.280 & 0.248 & 0.802 \\
C18:3 n-6 & 0.172 & 0.219 & 0.133 & 0.470 \\
C20:1 n-9 & 0.123 & 0.095 & 0.100 & 0.219 \\
C20:2 n-6 & 0.181 & 0.162 & 0.155 & 0.469 \\
C20:4 n-6 & 0.925 & 1.173 & 1.226 & 0.400 \\
C20:5 n-3 & 0.394 & 0.532 & 0.566 & 0.314 \\
Other FA, \% & 6.707 & 7.243 & 5.677 & \\
\hline \multicolumn{1}{c}{ Total } & 100 & 100 & 100 & \\
\hline Saturated (SFA, \%) & 46.974 & 45.16 & 46.48 & \\
Monounsaturated (MUFA, \%) & 37.903 & 39.637 & 39.439 & \\
Polyunsaturated (PUFA, \%) & 11.687 & 10.407 & 9.852 & \\
PUFA:SFA & 0.249 & 0.230 & 0.212 & \\
w-6: $\omega-3$ & 13.76 & 11.45 & 10.09 & \\
Atherogenic index & 0.73 & 0.61 & 0.64 & \\
Thrombogenic index & 1.76 & 1.69 & 1.82 & \\
\hline
\end{tabular}

Neither sex nor the castration method affects cholesterol levels of intramuscular fat (Table 2). Cholesterol is a substance naturally produced by the organism with important functions in the metabolism composed of high-density lipoproteins (HDL) (considered to be the good cholesterol) and low-density lipoproteins (LDL) (considered to be the bad cholesterol). Saturated fatty acids may increase the levels of LDL and the polyunsaturated ones reduce these levels. However, the total content of saturated, monounsaturated, and polyunsaturated fatty acids of the intramuscular fat were not affected.
Intramuscular fat participates with $20-35 \%$ of pork's lipid content (Gerbens, 2004) and the nutritional value of the meat is determined by the amount of lipids and their fatty acid profile. Font-i-Furnols et al. (2012) observed that the value obtained for MUFA was $1.2 \%$ higher for females compared to immunocastrated males, with an intermediate value for surgically castrated males.

Although the consumption of saturated fatty acids is associated with the occurrence and 
increase of bad cholesterol levels and the risk of coronary diseases, not all SFA are hypercholesterolemic. Stearic acid (C18:0), representing $15.96 \%$ of the total fatty acids in this study, has little effect on blood cholesterol levels in humans since it is little stored in some tissues and is immediately converted into oleic acid (C18:1) (French et al., 2003) by the endogenous enzyme

9-desaturase.

Lauric (C12:0) and myristic (C14:0) acids are highly hypercholesterolemic, however, the participation of these acids in the intramuscular fat was low at $0.02 \%$ and $1.12 \%$ of total fatty acids, respectively. On the other hand, palmitic acid (C16:0), the fatty acid that most impacts the levels of bad cholesterol, appeared at a greater proportion $(29.11 \%)$.

The unsaturated fatty acid which appears in the greatest amount is oleic acid $(34.34 \%)$. The essential fatty acids linolenic (C18:3n-3) and linoleic $(\mathrm{C} 18: 2 \mathrm{n}-6)$ comprise 0.31 and $8.15 \%$ of total fat, respectively.

According to Raes et al. (2004), the metabolism of linolenic and linoleic acids requires the same route of synthesis. Therefore, excess omega 6 fatty acids may interfere with the metabolism of omega 3 fatty acids, thereby reducing the synthesis and altering the biological effects of long-chain fatty acids such as docosapentaenoic $(\mathrm{C} 22: 5 n-3)$ and eicosapentaenoic (C20:5n-3) and, in turn, the metabolism of omega 6 results in the formation of arachidonic acid (C20:4n-6) (Daley et al., 2010).

Although eicosapentaenoic acid (with average content of $0.82 \%$ ) and arachidonic acid (with $1.07 \%$ ) act on opposing fronts in the processes of blood clot formation and blood vessel relaxation and constricttion, both are necessary to maintain the body's balance. For this reason, a $\omega-6: \omega-3$ ratio below 4 is recommended (Scollan et al., 2006). In this present study, the immunocastrated males showed the lowest $\omega-6: \omega-3$ ratio (10.09), slightly lower than the other groups, being closer to desired values.

While evaluating the $\omega-6: \omega-3$ ratio of pork, Yu et al. (2013) obtained values between $10.78 \%$ and $23.0 \%$, which were higher than those for beef (from 6.28 to $11.86 \%$ ). The authors concluded that the $\omega-6: \omega-3$ ratio was unbalanced and unhealthy and that the total amount of omega 3 does not meet the daily intake recommended by the American Heart Association (AHA) or the World Health Organization.

The impact of fat on cholesterol concentration can be observed through the atherogenicity index (AI), which includes those fatty acids that affect the change of cholesterol (in terms of both increase and decrease). If the AI of a certain food is lower, its atherogenic potential is also lower. Atherogenicity index values ranged from 0.66 to 0.77 and were higher than those observed by Alvarenga et al. (2014) in pork sausages (0.27 to $0.31)$.

\section{CONCLUSION}

The immunocastration technique was shown to be a safe alternative without compromises to the pork composition in terms of ether extract levels, cholesterol and fatty acid profile. Additionally, the myths related to the risk factors involved by the fat levels were clarified by the atherogenic and thrombogenic indexes of intramuscular fat kept in normal levels for pigs slaughtered at $90 \mathrm{~kg}$ of body weight even submitted to immunocastration.

Keywords: atherogenic index, cholesterol, fatty acid, immunocastration, swine, thrombogenic index

\section{RESUMO}

A presente pesquisa foi realizada com o objetivo de avaliar os níveis de colesterol, extrato etéreo, perfil de ácidos graxos e o índice aterogênico e trombogênico da gordura intramuscular de suínos machos imunocastrados em relação às fêmeas e aos machos castrados cirurgicamente. Utilizaram-se 45 animais,

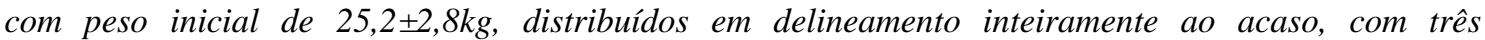
tratamentos (machos castrados, machos e fêmeas imunocastrados) e três repetições de cinco animais cada. Os animais foram abatidos a 90,3 $\pm 2,7 \mathrm{~kg}$. As amostras de Longissimus dorsi foram coletadas, liofilizadas e analisadas quanto ao perfil de ácidos gordos, colesterol e extrato etéreo. Não foram 
observadas diferenças $(P>0,05)$ para nenhuma das variáveis analisadas entre a gordura intramuscular de machos castrados cirurgicamente, machos imunocastrados e fêmeas. A imunocastração não alterou os níveis intramusculares de extrato etéreo, colesterol, composição de ácidos graxos ou o índice aterogênico e trombogênico do Longissimus dorsi.

Palavras-chave: índice aterogênico, colesterol, ácidos graxos, imunocastração, suínos, índice trombogênico

\section{REFERENCES}

ALVARENGA, A.L.N.; SOUSA, R.V.; PARREIRA, G.G.; CHIARINI-GARCIA, H.; ALMEIDA, F.R.C.L. Fatty acid profile, oxidative stability of pork lipids and meat quality indicators are not affected by birth weight. Animal, v.8, p.660-666, 2014.

COSGROVE, M.; FLYNN, A.; KIELY, M. Consumption of red meat, white meat and processed meat in Irish adults in relation to dietary quality. Br. J. Nutr., v.93, p.933-942, 2005.

DALEY, C.A.; AMBER-ABBOTT, A.; DOYLE, P.S.; NADER, G.A.; LARSON, S. Review of fatty acid profiles and antioxidant content in grass-fed and grain-fed beef. Nutr. J., v.10, p.112. 2010.

FONT-I-FURNOLS, M.; GISPERT, M.; GUERRERO, L. et al. Consumers' sensory acceptability of pork from immunocastrated male pigs. Meat Sci., v.80, p.1013-1018, 2008.

FONT-I-FURNOLS, M.; GISPERT, M.; SOLER, J. et al. Effect of vaccination against gonadotrophin-releasing factor on growth performance, carcass, meat and fat quality of male Duroc pigs for dry-cured ham production. Meat Sci., v.91, p.148-154, 2012.

FRENCH, P.; O'RIORDAN, E.G.; MONAHAN, F.J.; CAFFREY, P.F.; MOLONEY, A.P. Fatty acid composition of intra-muscular triacylglycerois of steers fed autumn grass and concentrates. Livest. Prod. Sci., v.81, p.307-317, 2003.
GERBENS, F. Genetic control of intramuscular fat accretion. Muscle Development of Livestock Animals. Physiology, Genetics and Meat Quality. $1^{\text {st }}$ ed. CAB International, 2004.

OFFICIAL methods of analysis. 18.ed. Gaithersburg: AOAC, 2011.

RAES, K.; DE SMET, S.; DEMEYER, D. Effect of dietary fatty acids on incorporation of long chain polyunsaturated fatty acids and conjugated linoleic acid in lamb, beef and pork meat: a review. Anim. Feed. Sci. Tech., v.113, p.199-221, 2004.

STATISTICAL ANALYSIS SYSTEM - SAS. System for Microsoft Windows: release 8.2. Cary: 2001. 1 CD-ROM.

SCOLLAN, N.; HOCQUETTE, J.F.; NUERNBERG, $\mathrm{K}$. et al. Innovations in beef production systems that enhance the nutritional and health value of beef lipids and their relationship with meat quality. Meat Sci., v.74, p.17-33, 2006 .

ULBRICHT, T.L.V.; SOUTHGATE, D.A.T. Coronary heart disease: seven dietary factors. Lancet, v.338, p.985-992, 1991.

YU, M.; GAO, Q.; WANG, Y. et al. Unbalanced omega-6/omega-3 ratio in red meat products in China. J. Biomed. Res., v.27, p.366-371, 2013.

ZAMARATSKAIA, G.; ANDERSSON, H.K.; CHEN, G. et al. Effect of a gonadotropinreleasing hormone vaccine (Improvac (TM)) on steroid hormones, boar taint compounds and performance in entire male pigs. Reprod. Domest. Anim., v.43, p.351-359, 2008. 